\title{
Influence of biopreparations on biomass yield and grain efficiency of energy corn
}

\author{
Zoya Pustova, Natalia Pustova, Serhii Komarnitskyi, Oleg Tkach, Stepan Zamoiskyi and \\ Alexander Olenyuk,*
}

State Agrarian and Engineering University in Podilia, 32300 Kamianets-Podilskyi, Ukraine

\begin{abstract}
The possibilities of using resources of the plant biomass as an effective renewable energy source are analyzed. The issues of the current state of corn for grain production, peculiarities of its cultivation and the possibility of using agrarian residues in corn production to produce energy are considered in the study.
\end{abstract}

\section{Introduction}

Currently the dominant global trend in the energy sector is increasing the cost of natural products and gradual replacement of traditional energy resources by the analogues of plant origin, which, on the one hand, eliminates the dependence from the traditional fuels, and, on the other hand, reduces the pollution of the environment, creates new strategies for using the vegetable biomass crops. Undoubtedly Ukraine is looking for cheap biofeedstock, new technological solutions and the necessary infrastructure for cultivation and biomass processing on the basis of chemical and biological processes, thermo conversion, bioconversion in various biofuels: liquid, gaseous and solid. Consequently, the use of vegetable biomass (straw) is becoming increasingly important in the form of solid biofuels to increase energy autonomy [1].

The significant growth of bioenergy in the EU from 74 million tons in 2005 to 140 million tons in 2016 and the expected contribution of biomass to the energy balance, which in accordance with the National Renewable energy action plans in general must be equal to 180 million tons in 2020 and 235 - 282 million tons in 2030 for the EU. The potential of the biomass is large, but at the same time is characterized by strong uncertainty. For example, in 2030 it will be 235 - 375 million tons, and especially in the long-term estimate it will be equal to $195-505$ million tons until 2050. The researches carried out for the EU countries, as well as Ukraine have defined the theoretical, as well as technical, ecological and sustainable potential of crop residues, the necessity to collect the agricultural residues on the basis of sustainability and taking into account the peculiarities of various plant varieties, competitive use and annual fluctuations in yield, as well as the application of compensation means for the maintenance of soil fertility (green and mineral fertilizers, manure) [2].

\footnotetext{
*Corresponding author: pro-gp@pdatu.edu.ua
} 
A big potential of biomass in Ukraine belongs to agricultural residues, which also have the name of harvest remains of agricultural products are represented, primarily, by cereal straw and stems of maize.

The plant biomass resources are effective renewable source of energy in agriculture and are available in all regions of Ukraine. What is important, they can be processed into energy and fuel without any difficulties. Biomass is called an organic substance, which is produced by plants as a result of photosynthesis. Wood and vegetable biomass of energy crops should be attributed to ordinary forms of biomass. Much of biomass is formed in the production and processing of crop production in the form of by-products: straw, stems, sunflower husk, corn forks, etc. The ratio grain part of the crop and not grain (straw) is approximately 1:1 (for corn, this figure is $1: 1.3-1.5$ ), so the annual volume of straw formation is close to the overall production.

The use of vegetable biomass for bioenergy needs can be conducted through direct combustion, biogas production from agricultural and domestic wastes, or ethyl alcohol production to obtain motor fuels. The main potential is agricultural waste-straw of grain crops, the stems of rapeseed, maize and sunflower. As a result of scientific analysis it has been established that the highest economic potential of the plant biomass waste has by products of oilseeds (rapeseed, sunflower), with the total coefficient of $1.34-1.40$, somewhat lower - the stems of maize $(0.74)$, and the smallest - cereal straw and leguminous crops $0.10-0.13[1]$.

If we consider the types of high-performance energy crops that can be used to produce solid biofuel, they are: $[1,14]$.

- Permanent cereals (Miscanthus, Millet lososimilar, Kostrytsya, etc.), with the term of collection and use in $2-3$ years;

- Woody crops (hybrid willow, poplar, etc.). As a rule, these cultures are fast-growing and can be used within $10-20$ years after the planting;

- Agricultural crops (waste of production and processing). The volume of biological waste crops is significant, and their specific weight depends on the type, methods of collection, processing, etc.

- The last of the type of energy crops should paid close attention to as they have a number of significant advantages, such as:

- the annual renewal and have a poorly used resource;

- Do not require special technologies for their cultivation, because they are by products;

- Minimum capital expenditure on the purchase of mechanization funds for storing up by products;

- Low cost of by crops products as the main raw material for biofuel production [1].

Soil and climatic conditions in most regions of Ukraine are favourable for cultivation of both high-performance energy and agricultural crops, which in the process of processing can serve as a source for biofuel production. In terms of energy biomass agricultural production wastes make up about $4.8 \%$, but their peculiarity is that they are renewed annually and are not frequently used resources.

The purpose of the research was to determine the peculiarities of mycorhization, growth regulators and plant development in the growth, development and formation of grain productivity and biological waste of plants for the preparation of biofuel hybrids of maize in the Western Forest-Steppe of Ukraine.

Experiments were carried out in the field crop rotation of the experimental field of the State Agrarian and Engineering University in Podillia, which, under the conditions of heat supply and humidification, belongs to the southern moist agro-climatic region. Within the framework of the following research subject: State Agrarian and Engineering University in Podillia: «Agrobiomass of Ukraine for power potential of Central and Eastern Europe», corn 
was chosen as the basic culture for the research, because it is a promising source of raw materials for energy both in the production of ethanol and vegetable oils, and as biomass for increasing the resource of solid fuels.

\section{Research methods}

The soil of the State Agrarian and Engineering University in Podilia field is typical black currant with little humus, heavy loamy on the loess. The experimental area was characterized by the following agrophysical and agrochemical properties of the soil: the content of humus (by Tyurin) - 3.8-4.4\%, alkaline hydrolyzed nitrogen (by Cornfield) - 122-126, the content of mobile phosphorus by Chirikov - 90-120, exchangeable potassium - 190-230 mg per kg of soil, the capacity of absorption and the amount of absorbed elements, respectively, 32-34 and $30-33 \mathrm{mg} / \mathrm{eq}$. per $100 \mathrm{~g}$ of soil. Hydrolytic acidity is $2.3-2.8 \mathrm{mg} / \mathrm{eq}$. per $100 \mathrm{~g}$ of soil, and the degree of saturation with the elements - is close to absolute $-94.7-99.0 \%$. The sown area of the unitary field was 45.0 , and the accounting $-25.2 \mathrm{~m}^{2}$ in four-time repetition.

The sown area of the unitary field was 45.0 , and the accounting $-25.2 \mathrm{~m}^{2}$ in four-time repetition. Посів здійснювали в третій декаді квітня. Для посіву використовували гібриди кукурудзи різних груп стиглості. Попередник - соя. Застосовували регулятори росту Agrostimulin i Zeastimulin на кукурудзі звичайній (Zea mays) української і закордонної селекції: Ariia, PR39H32 Pioneer, DK 315 Monsanto. The sowing was carried out in the third decade of April. Corn hybrids of different groups of ripeness were used in sowing. Predecessor was soya. Agrostimulin and Zeastimulin growth regulators were used with corn ordinary (Zea mays) of Ukrainian and foreign breeding: ARIIA, PR39H32 Pioneer, DK 315 Monsanto. In order to settle the root and root area with micorrhizal fungi and saprophytic rhizospheric bacteria Melanoriz ${ }^{\circledR}$ (manufacturer of BTU-Center Ukraine) was used. In our study, we conducted two spraying of crops during the vegetation of plants, in the following periods: 1) 4-6 real leaves; 2) 8-10 real leaves. The mentioned phase was established when at least $75 \%$ of the plants were included in it. Corn cultivation technology is common for the zone, except the investigated elements of technology.

\section{Results and Discussion}

Corn is -high-performance plant of tropical origin. Its homeland is Middle and South America, explaining the needs of plants in the heat for its growth and development. Maize for a short period of time yields more organic mass than other cultivated plants. Thanks to the progress in breeding areas the maize growing zones have advanced far northward in recent years.

Corn grain is a valuable raw material and is widely used in various sectors of the processing industry: starch, food, medical. We produce flour, grain, alcohol, glucose, molasses, oil and many other products. Peeled forks are used for making furfurol, plastics, and other products. We also get greens, juicy feed from corn. According to the content of feed units per hectare it is somewhat inferior to the beet and all silage crops predominates $[5]$.

USA is a world leader in gross harvest and the yield of corn for grain. In $2014-2015$ marketing year 361 million tons (36.4\% global harvest of this crop) of corn was harvested in this country, getting an average $107.3 \mathrm{c} / \mathrm{ha}$. China also produces about 216 million tons of corn for grain (Brazil - 85 million tons of corn for grain, EU - 76 million tons of corn for grain, Ukraine-28.5 million tons of corn for grain) in 2014 - 2015 marketing year.. Heavy yield of maize is connected with the development of agricultural science and the use of biotechnology to create hybrids, which since 2000 provides a growth of yields in the United 
States of $2 \%$ annually. At comparative tests American farmers reach the yield of corn for grain over $250 \mathrm{c} / \mathrm{ha}$. In 2015, the National Association of Corn Producers announced the establishment of a world record in Virginia - more than 334 c/ha of Grain Grade Pioneer ${ }^{\circledR}$ P1197AM ${ }^{\text {TM }} 1$ corn $[7,8]$.

Corn for grain and grain-pivot mixture takes the gross second place among cereals in the EU. Besides, corn is cultivated, primarily, for grain. 75.7 million tons of grains and 2.4 million tons of the grain-pivot mixture were harvested in 2014. France produces 18.4 million tons of corn for grain (it is $24.3 \%$ of the EU gross collection in 2014, Romania-11.73 million tons, Hungary-9.17 million tons and Italy- 8.33 million tons. The highest yield was in Spain112.4 c/ha, Austria-107.9 c/ha, Germany-106.8 c/ha and France-103.8 c/ha [8].

The highest gross harvest of corn for grain in Europe is obtained in Ukraine. Gross production of corn in 2018-2019 the marketing year was about 35.6 million tons, which is almost 11 million tons more than in the previous marketing year (Table 1). Such a leap was achieved through favourable conditions during the vegetation period of culture that caused high yield culture at the average of $7.8 \mathrm{t} / \mathrm{ha}$ (at annual $5.5-6.6 \mathrm{t} / \mathrm{ha}$ ). The record gross collection resulted in the growth of export of culture - almost 10 million tons in comparison to 2017 - 18 marketing year [9].

Table 1. Production and consumption of corn in Ukraine

\begin{tabular}{|l|c|c|c|c|c|}
\hline $\begin{array}{l}\text { Balance of corn, } \\
\text { thousand tons }\end{array}$ & $\mathbf{2 0 1 4 / 1 5}$ & $\mathbf{2 0 1 5 / 1 6}$ & $\mathbf{2 0 1 6 / 1 7}$ & $\mathbf{2 0 1 7 / 1 8}$ & $\mathbf{2 0 1 8 / 1 9 *}$ \\
\hline $\begin{array}{l}\text { Початкові запаси } \\
\text { Initial inventories }\end{array}$ & 1992 & 2130 & 1354 & 1796 & 1631 \\
\hline $\begin{array}{l}\text { Collected area, } \\
\text { thousand ha }\end{array}$ & 4627 & 4084 & 4252 & 4481 & 4557 \\
\hline Yield, tons/ha & 6,2 & 5.7 & 6.6 & 5.5 & 7.8 \\
\hline Production & 28497 & 23328 & 28075 & 24669 & 35569 \\
\hline Import & 30 & 30 & 28 & 40 & 33 \\
\hline Total Offer & $\mathbf{3 0 5 1 8}$ & $\mathbf{2 5 4 6 1}$ & $\mathbf{2 9 4 5 7}$ & $\mathbf{2 6 5 0 5}$ & $\mathbf{3 7 2 3 2}$ \\
\hline Export & 19683 & 16672 & 21281 & 17870 & 27589 \\
\hline Feed consumption & 6475 & 5802 & 4629 & 4946 & 5889 \\
\hline Food processing & 124 & 126 & 130 & 126 & 122 \\
\hline $\begin{array}{l}\text { Industrial } \\
\text { consumption }\end{array}$ & 535 & 471 & 631 & 893 & 516 \\
\hline Seeds & 549 & 509 & 518 & 453 & 451 \\
\hline Loss & 186 & 140 & 140 & 140 & 117 \\
\hline $\begin{array}{l}\text { Internal } \\
\text { distribution }\end{array}$ & $\mathbf{2 8 4 1 5}$ & $\mathbf{2 4 1 0 6}$ & $\mathbf{2 7 6 6 2}$ & $\mathbf{2 4 8 7 4}$ & $\mathbf{3 5 5 8 2}$ \\
\hline Trailing balances & 2103 & 1354 & 1796 & 1631 & 1650 \\
\hline
\end{tabular}

*Predictive information

Source: The automated balance of supply and demand for grain in Ukraine, FAO/EBRD

There are four agricultural climatic zones for maize in Ukraine: steppe, forest-steppe, forest area, mountainous areas of the Carpathians and the Crimea steppe. Each zone has soil features, moisture conditions and temperature, which significantly affect the crop. The period when corn can actively develop and accumulate organic matter, is limited by date of steady transition of average daily air temperature at $10^{\circ} \mathrm{C}$. An important feature of the thermal regime of corn is its duration in conjunction with a high moisture adsorptivity [4].

When growing maize, except the basic products (grain), a lot of by products are formed - stems, leaves, wrappers and rests of cabbage heads, which can be used as raw material for biofuel and biogas production. Modern technologies for harvesting corn on grain practice leaving the by-products on the fields. If the combines are not equipped with choppers, there 
is a need to use cutters, aggregated with tractors, which allow to qualitatively grind and distribute plant residues on the surface of the field

In Ukraine, the by-products of corn for grain are mainly used as fertilizer, for growing mushrooms in protected ground, as well as by-products are traditionally used in livestock as food and bedding and in some regions - as solid biofuel, namely, rectangular and round totes, granules and briquettes $[1,11]$. The unused rests are often burned in the fields, which is officially banned in Ukraine and is very harmful to the environment and soil [12].

For energy purposes, corn is used in various forms. Plant rests of corn in the form of leafstalk mass, maize rods are often used for direct combustion or for the production of various types of solid fuels. The grain part of the corn harvest is used to produce ethanol and vegetable oils, which are the basis of liquid fuels. Therefore, when growing corn for grain its energy potential can be fully used. For example, corn cods can be used to produce fuel granules when threshing the beginnings of corn at stationary points. The characteristics of granules represented in the Ukrainian market are as follows: diameter $6-8 \mathrm{~mm}$, humidity $7.3 \%$, ash content $2.6 \%$, lower heat of combustion $4168 \mathrm{kcal} / \mathrm{kg}(17.4 \mathrm{~mJ} / \mathrm{kg})[1,11,13]$.

Biomass as energy resources is widely used in the agriculture of Poland, Hungary, the Czech Republic, in particular, such agricultural by products as straw of cereals, corn and sunflower stalks, etc. These energy resources can be effectively used if they are located at a short distance from the heating facility. Thus, the straw is burned in the form of briquettes, pressed rolls or bales of rectangular section or in crushed form. At the same time, harvesting of straw is most effectively carried out when pressed in rolls or bales. Application of fixation in the form rolls makes their energy usage easier.

The burning of biomass is the oldest and easiest way to obtain energy, but in many cases this method is considered to be economically feasible. The heterogeneity of biomass, in terms of chemical composition and physical properties, causes certain difficulties both in the process of combustion and emission of components that are side products of the process $[1$, $11,15,16,17,18]$.

The industrial harvesting of byproducts of corn for grain is frequently used in the world. Thus, in the US the plant specialized in the production of bioethanol from the lignocellulosic raw materials of Du Pont Company (Nevada, Iowa) is able to process 375 thousand tons of corn straw annually. At this, the alienation of biomass is carried out on the principles of sustainable development in fulfilling the conditions and recommendations of natural Resources Conservation Service of the USA. In determining the volume of harvesting of byproducts of corn for grain in Ukraine the balance of humus and nutrients must be taken into account, to avoid such consequences as erosion and deterioration of characteristics of the soil. Recently high price for energy resources made the farmers to work out the technology of corn for grains harvesting based on application of modern equipment, in particular, high-performance Baling machines. You can expect the volume of byproducts usage of corn for grain in the energy sector will increase, because it has better burning characteristics than straw of grains.

According to the ash melting characteristics corn straw is similar to the wood biomass. To harvest the byproducts of corn for grain for energy use it is necessary to reduce the biomass humidity to $20 \%$. It is necessary to coordinate the working plans of the harvesting company with the weather forecast. A properly selected technology and equipment are important factors to ensure the proper quality of biomass [4].

The share of by-products of grain for corn for alienation and further energy use is determined mainly by yields, but it can be adjusted by making reasonable norms of mineral and organic fertilizers (Table 2) [5].

Table 2 Procedure for determining the byproducts volume of corn for grain for alienation

\begin{tabular}{|l|l|}
\hline Condition & Limitation \\
\hline
\end{tabular}




\begin{tabular}{|l|l|l|}
\hline & Minimum & Maximum \\
\hline Agroclimatic Zone & Forest Steppe, Forest area & Steppe \\
\hline Crop rotation & Re-Corn & $\begin{array}{l}\text { After sunflower and sugar } \\
\text { beets }\end{array}$ \\
\hline Yield of basic Products & More than 8.0 t/ha & Less than 8.0 t/ha \\
\hline Moisture & $\begin{array}{l}\text { The degree of moisture supply } \\
\text { in the root soil layer is more } \\
\text { than 60\% }\end{array}$ & $\begin{array}{l}\text { Less than } 30 \text { mm of } \\
\text { precipitation per month }\end{array}$ \\
\hline Erosion & $\begin{array}{l}\text { Slope of the field surface to } 4 \\
\text { presence of protective } \\
\text { timber strips }\end{array}$ & $\begin{array}{l}\text { Tilt the field surface more than } \\
4^{\circ}\end{array}$ \\
\hline Soil cultivation Technology & No-till, Minimum & Ploughing \\
\hline Fertilizers & Organic and mineral & Only mineral \\
\hline Balance of Humus & Positive & Negative \\
\hline $\begin{array}{l}\text { Weather conditions during } \\
\text { harvesting }\end{array}$ & Dry weather & Heavy rainfall \\
\hline
\end{tabular}

Significant reserve of increasing the yield of corn and the improvement of grain quality are plant growth regulators and microbiological preparations that increase the yield of grain and green mass by $10-20 \%$, or $0.5-0.9 \mathrm{t} / \mathrm{ha}$ of grain and $3.0-9.0 \mathrm{t} / \mathrm{ha}$ of green mass. Seed treatment regulators of growth are combined with treatment and microelements processing. Effectiveness of growth regulators in the treatment of seeds and spraying of crops is almost identical. It has been determined that growth regulators accelerate plant growth and development, increase their resistance to high temperatures and dry weather. Spraying of maize crops with the regulators of growth are carried out in the development phase of $3-9$ leaves in tank mixtures with insurance herbicides. Rates of growth regulators per 1 hectare are the following: Zeastimulin $-15 \mathrm{ml}$, Agrostimulin $-20 \mathrm{ml}$.

Crops are sprayed with flow rate of working solution $250-3001 /$ ha. The combination of pre-seeding treatment of seeds and spraying of crops by regulators of growth accelerates the development of plants, increases the resistance of plants to high temperatures, enhances the development of the leaf surface, increases the content of chlorophyll, increases the content of protein and fat, increases grain harvest by $0.7-1.5 \mathrm{t} / \mathrm{ha}$ and green mass by $5.0-10.0 \mathrm{t} / \mathrm{ha}$ [6].

We also used mycorrhizal forming drug Melanorisis in our study.

Melanoriz ${ }^{\circledR}$ Complex mycorrhizal preparation for nutrition and protection against diseases, detoxicant.

Application effect:

- activates colonization of root and rhizosphere by mycorrhizal fungi and saprophytic rhizosphere bacteria;

- $\quad$ increases the area of absorption by the root system of plants due to formation and development of mycorrhiza;

- neutralizes in soil the toxic effects of pathogenic microorganisms, pesticides, manmade factors;

- contributes to development of natural antibiotics by colonized fungi and bacteria and inhibition of pathogens development (fusarium blight, late blight, alternariosis, black, basal bacteriosis, etc.) and pests (nematodes, etc);

- improves seed germination and survival of seedlings;

- improves plant immunity;

- $\quad$ provides plants with nutrients in an easily accessible form necessary for growth and development.

According to the results of the research conducted at State Agrarian and Engineering University in Podillia, the positive influence of bio stimulators and microbiological 
preparations, both on the gain of grain and the increase of the byproducts was revealed, and consequently the potential resource of raw materials for different types of biofuels.

In conducted research the processing of corn crops on grain by growth regulators was carried out in the following terms: 1) 4-6 real leaves; 2) 8-10 real leaves. This phase was established when at least $75 \%$ of the plants were included in it.

The obtained results indicate a positive effect on the combination of preseeding treatment of corn seeds by the Melanoriz-forming Drug ${ }^{\circledR}$ with the subsequent use of Agrostimulin and Zeastimulin growth regulators in critical growth periods the crop. The increase in yield control was Zeastimulin $-0.57-1.32 \mathrm{t} / \mathrm{ha}$, Agrostimulin $-0.60-1.60 \mathrm{t} / \mathrm{ha}$ (Table 3). The protein content in grain has also changed in positive way: Zeastimulin $5.58-6.60 \%$, and Agrostimulus $-5.59-6.70 \%$. The studied hybrids had different levels of yields: Ariia -9.60 - $11.01 \mathrm{t} / \mathrm{ha}$, PR39H32 Pioneer - 9.28 - 9.99 t/ha and DK 315 Monsanto - $10.96-12.56$ $\mathrm{t} / \mathrm{ha}$. The use of growth regulators in phase 4-6 of leaves and in 8-10 of leaf phase activates biochemical processes in plants, which causes not only increase in yield of corn for grain, but also improvement of product quality.

The application of growth regulators on the basis of a microbiological product with corn in our researches caused high grain productivity of plants and biomass. The better nutrition of corn - the more intensive is the process of growing.

The height of cereals characterizes the stem size, reflecting the general state of the plant, including the size of the biomass, reflecting the conditions of cultivation. Positive correlation dependence is set between yield and plant height. The most intensive increase in the length of the stem is observed at 7-8 stages (increased growth of inflorescences) of organogenesis. The results of the study on dynamics of biomass increasing showed a substantial increase in corn biomass after application of growth regulators (Table 4). Obviously, in phase $4-6$ leaves, when the corn plant passes to the root nutrition and begins to intensively build up vegetative mass, foliage application of growth regulators intensifies the synthesis of organic matter. In conducted researches the accumulation of biomass in plants was as follows: Zeastimulin $-0.21-1.30 \mathrm{t} / \mathrm{ha}$, Agrostimulin $-0.25-0.32 \mathrm{t} / \mathrm{ha}$. The hybrids of corn in the phase of complete ripeness provided a different amount of green mass, which can be used to obtain biofuels: Ariia - 23.52 - 29.98 t/ha, PR39H32 Pioneer - 28.43-35.26 t/ha and DK 315 Monsanto $-31.51-45.80 \mathrm{t} / \mathrm{ha}$.

Table 3 Corn yield hybrids according to the processing of seeds and foliar application

\begin{tabular}{|c|c|c|c|c|c|}
\hline \multirow{2}{*}{$\begin{array}{l}\text { Hybrid } \\
\text { (Factor A) }\end{array}$} & \multirow{2}{*}{$\begin{array}{l}\text { Presowing seed } \\
\text { treatment (factor } \\
\text { B) }\end{array}$} & \multirow{2}{*}{$\begin{array}{l}\text { Foliar } \\
\text { fertilizing } \\
\text { (Factor c) }\end{array}$} & \multicolumn{2}{|l|}{ Yield } & \multirow{2}{*}{$\begin{array}{l}\text { Protein } \\
\text { content, } \\
\%\end{array}$} \\
\hline & & & $\mathrm{T} / \mathrm{ha}$ & $\begin{array}{l} \pm \quad \text { before } \\
\text { control }\end{array}$ & \\
\hline \multirow{6}{*}{ Ariia } & \multirow{3}{*}{$\begin{array}{l}\text { Without } \\
\text { processing }\end{array}$} & 1 & 9,60 & - & 5,66 \\
\hline & & 2 & 10,26 & $+0,66$ & 6,24 \\
\hline & & 3 & 10,34 & $+0,74$ & 6,25 \\
\hline & \multirow{3}{*}{ Melanorii } & 1 & 10,22 & $+0,62$ & 5,58 \\
\hline & & 2 & 10,93 & $+1,33$ & 6,62 \\
\hline & & 3 & 11,01 & $+1,41$ & 6,67 \\
\hline \multirow{6}{*}{$\begin{array}{l}\text { PR39H32 } \\
\text { Pioneer }\end{array}$} & \multirow{3}{*}{$\begin{array}{l}\text { Without } \\
\text { processing }\end{array}$} & 1 & 9,28 & - & 6,00 \\
\hline & & 2 & 9,84 & $+0,56$ & 5,63 \\
\hline & & 3 & 9,99 & $+0,71$ & 6,66 \\
\hline & \multirow{3}{*}{ Melanorii } & 1 & 9,85 & $+0,57$ & 5,58 \\
\hline & & 2 & 10,44 & $+1,16$ & 6,30 \\
\hline & & 3 & 10,60 & $+1,32$ & 6,60 \\
\hline
\end{tabular}




\begin{tabular}{|l|l|l|l|l|l|}
\hline & \multirow{4}{*}{$\begin{array}{l}\text { Without } \\
\text { DK }\end{array}$} & 1 & 10,96 & - & 6,00 \\
\cline { 2 - 6 } & 2 & 11,59 & $+0,63$ & 6.24 \\
\cline { 2 - 6 } & & 3 & 11,99 & $+1,03$ & 6,67 \\
\cline { 2 - 6 } & \multirow{3}{*}{ Melanorii } & 1 & 11,56 & $+0,60$ & 6,70 \\
\cline { 3 - 6 } & 2 & 12,34 & $+1,38$ & 5,59 \\
\cline { 3 - 6 } & 3 & 12,56 & $+1,60$ & 6,66 \\
\hline НIP0,5 т/га & $\mathrm{A}=0,090, \mathrm{~B}=0,064, \mathrm{C}=0,078, \mathrm{AB}=0,127, \mathrm{AC}=0,156, \mathrm{BC}=0,110, \mathrm{ABC}=0,220$ \\
\hline
\end{tabular}

Note: 1. Without feeding (spraying water); 2. Zeastimulin - $15 \mathrm{ml} / \mathrm{ha}$; Agrostimulin $-20 \mathrm{ml} / \mathrm{ha}$.

Table 4 The dynamic of formation of corn green mass, $t /$ ha

\begin{tabular}{|c|c|c|c|c|c|c|}
\hline \multirow{2}{*}{$\begin{array}{l}\text { Hybrid } \\
\text { (Factor A) }\end{array}$} & \multirow{2}{*}{$\begin{array}{l}\text { Presowing } \\
\text { treatment } \\
\text { B) }\end{array}$} & \multirow{2}{*}{$\begin{array}{l}\text { Foliar } \\
\text { fertilizing } \\
\text { (Factor c) }\end{array}$} & \multicolumn{4}{|c|}{ Phase of growth and development of corn plants } \\
\hline & & & \begin{tabular}{|l|}
$4-6$ \\
leaves
\end{tabular} & $\begin{array}{l}9-10 \\
\text { leaves }\end{array}$ & \begin{tabular}{|l|} 
Ejection \\
of Panicon
\end{tabular} & $\begin{array}{l}\text { Full } \\
\text { ripeness }\end{array}$ \\
\hline \multirow{6}{*}{ Ariia } & \multirow{3}{*}{$\begin{array}{l}\text { Without } \\
\text { processing }\end{array}$} & 1 & 0,18 & 9,25 & 30,90 & 23,52 \\
\hline & & 2 & 0,21 & 9,80 & 31,42 & 25,94 \\
\hline & & 3 & 0,25 & 10,10 & 35,23 & 27,96 \\
\hline & \multirow{3}{*}{ Melanorii } & 1 & 0,20 & 9,98 & 34,95 & 28,52 \\
\hline & & 2 & 0,25 & 10,02 & 35,24 & 29,98 \\
\hline & & 3 & 0,28 & 13,43 & 40,90 & 29,21 \\
\hline \multirow{6}{*}{$\begin{array}{l}\text { PR39H32 } \\
\text { Pioneer }\end{array}$} & \multirow{3}{*}{$\begin{array}{l}\text { Without } \\
\text { processing }\end{array}$} & 1 & 0,21 & 12,85 & 43,50 & 28,43 \\
\hline & & 2 & 0,27 & 13,91 & 46,43 & 29,37 \\
\hline & & 3 & 0,28 & 15,05 & 57,44 & 32,29 \\
\hline & \multirow{3}{*}{ Melanorii } & 1 & 0,26 & 11,52 & 53,91 & 29,41 \\
\hline & & 2 & 0,30 & 12,97 & 56,22 & 32,65 \\
\hline & & 3 & 0,31 & 9,23 & 58,92 & 35,26 \\
\hline \multirow{6}{*}{$\begin{array}{l}\text { DK } 315 \\
\text { Monsanto }\end{array}$} & \multirow{3}{*}{$\begin{array}{l}\text { Without } \\
\text { processing }\end{array}$} & 1 & 0,19 & 12,35 & 32,65 & 31,51 \\
\hline & & 2 & 0,24 & 14,31 & 36,11 & 35,25 \\
\hline & & 3 & 0,26 & 15,63 & 37,24 & 36,85 \\
\hline & \multirow{3}{*}{ Melanorii } & 1 & 0,21 & 13,65 & 36,03 & 35,43 \\
\hline & & 2 & 0,23 & 14,86 & 43,76 & 42,90 \\
\hline & & 3 & 0,25 & 16,89 & 48,36 & 45,80 \\
\hline
\end{tabular}

Note: 1. Without feeding (spraying water); 2. Zeastimulin - $15 \mathrm{ml} / \mathrm{ha}$; Agrostimulin - $20 \mathrm{ml} / \mathrm{ha}$.

\section{Conclusions and recommendations}

Energy sector is one of the most important and integral components of the economic complex of Ukraine. At the same time, energy security is one of the weakest components of national security of our country. An up-to-date task is to reduce the consumption of expensive imported fuel such as natural gas and oil, and to create own alternative renewable of energy sources with the simultaneous solution of ecological problems and development of energy saving technologies. According to leading experts in the field of bioenergy, the economic potential of biomass is about 30 million. tones per year, which can provide up to $14 \%$ of Ukraine's needs in primary energy, of which 17 million tons are available today [1].

Biological drugs Zeastimulin and Agrostimulin, as well as microbiological preparation Melanoriz ${ }^{\circledR}$ used in our research positively influenced both the increase of biomass and grain productivity of energy corn. The highest yield was fixed with the variant of hybrid of DK 315 Monsanto $12.56 \mathrm{t} / \mathrm{ha}$, which provided the amount of green mass of waste $-45.80 \mathrm{t} / \mathrm{ha}$, 
respectively, the potential resource of raw materials for production of different types of biofuels of energy corn became higher at $30 \%$.

\section{References}

1. O. Haidenko Pravylna zahotivlia biomas Mekhanizatsiia APK veresn (2014).

2. Materialy Seminaru «Ahrovidkhody dlia bioenerhetyky. Problemy ta rishennia» 27 veresnia (2018). http://www.uabio.org/events/events/3917-nl-workshop-agroresiduesfor-bioenergy-problems-and-solutionsmaterials?highlight=WyJcdTA0M2FcdTA0NDNcdTA0M2FcdTA0NDNcdTA0NDBc dTA0NDNcdTA0MzRcdTA0MzdcdTA0MzAiXQ

3. Kukurudza. Vyroshchuvannia, zbyrannia, konservuvannia i vykorystannia. Pid zahalnoiu redaktsiieiu D.Shpaara. K.: Alfa-steviia LTD (2009).

4. Tsykov V.S. Kukuruza: tekhnolohyia, hybryd, semena. Tsykov V.S. Dnepropetrovsk: Yzdatelstvo Zoria (2003)

5. Yermakova L. M., Krestianinov Ye. V. Urozhainist kukurudzy zalezhno vid udobrennia ta hibrydu na temno-sirykh opidzolenykh gruntakh No 4, pp. 63-65 (2016)

6. Volkohon, V. V., Nadkernychna, O. V., Kovalevska, T. M. Mikrobni preparaty u zemlerobstvi. Teoriia i praktyka [Microbial preparations in agriculture. Theory and practice]. Kiev: Agrarian Science, 312 (2006)

7. DuPont Reports Virginia Grower Breaks World Corn Yield Record with Pioneer(R) Brand Corn http://www.globenewswire.com/newsrelease/2015/12/18/796991/10158667/en/DuPont-Reports-Virginia-Grower-BreaksWorld-Corn-Yield-Record-with-Pioneer-R-Brand-Corn.html

8. S. Dragnev, T. Zheliezna, G. Geletukha Opportunities for harvesting by-productsof grain corn for energy production in Ukraineu ABio Position Paper N 16 (2016) http://www.uabio.org/img/files/docs/position-paper-uabio-16-en.pdf

9. http://ucab.ua/ua/doing_agribusiness/agrarni_rinki/zernovi

10. Sokolik S.P. Perspektyvy vykorystannia kukurudzy na zerno v yakosti biopalyva http://dspace.khntusg.com.ua/bitstream/123456789/4240/1/25.pdf

11. S.V. Klius. Vyznachennia enerhetychnoho potentsialu solomy i roslynnykh vidkhodiv za period nezalezhnosti Ukrainy. Vidnovliuvana enerhetyka, N 3 (2012)

12. Georgiy Geletukha, Tetiana Zheliezna. Prospects for the use of agricultural residues for energy production in Ukraine. UABio Position Paper N7. http://www.uabio.org/img/files/docs/Position-paper-UABIO-7-EN.pdf

13. Serhii Yermakov, Taras Hutsol, Sergii Slobodian, Serhii Komarnitskyi, Myroslav Tysh Possibility of Using Automation Tools for Planting of the Energy Willow Cuttings Renewable Energy Sources: Engineering, Technology, Innovation. Springer International Publishing AG, ISSN 2352-2542 (electronic), ISSN 2352-2534. pp. 419429 (2018) https://link.springer.com/chapter/10.1007/978-3-030-13888-2_42

14. Volodymyr Ivanyshyn, Ulyana Nedilska, Veronika Khomina, Rita Klymyshena, Vasil Hryhoriev, Oleg Ovcharuk, Taras Hutsol, Krzysztof Mudryk, Marcin Jewiarz, Marek Wróbel, Krzysztof Dziedzic Renewable Energy Sources: Engineering, Technology, Innovation. Springer International Publishing AG, ISSN 2352-2542 (electronic), ISSN 2352-2534. pp. 801-812 (2018)

15. O. Kucher, T. Hutsol, K. Zavalniuk, Y. Pantsyr, I. Harasymchuk, K. Mudryk, M. Jewiarz. Marketing strategies and prognoses of development of the Renewable Energy market in Ukraine. Scientific Achievements In Agricultural Engineering Agronomy And Veterinary Medicine. Traicon SC. Vol. II, No. 1, pp. 100-121 (2017) http://188.190.33.56:7980/jspui/bitstream/123456789/905/4/SAAEAVM-100-121.pdf 
16. O. Kucher, L. Prokopchuk The Development of the Market of Renewable Energy in Ukraine. Renewable Energy Sources: Engineering, Technology, Innovation. Springer International Publishing AG, ISSN 2352-2542 (electronic), ISSN 2352-2534. pp. 71-82 (2018)

17. V. Ivanyshyn, O. Kucher, T. Bilyk Marketing Strategy Formation for the Development of Organic Production in the Ukraine Proceedings of the 2018 International Scientific Conference Economic Sciences for Agribusiness and Rural Economy No 1, Warsaw, 78 June 2018, pp. 34-39 (2019)

18. M. Misiuk, O. Kucher, M. Zakhodym, Y. Ievstafiieva Marketing Concepts in the Formation of the Biomass Market in Ukraine Renewable Energy Sources: Engineering, Technology, Innovation ICORES 2018 pp. 209-216 (2018). 